\title{
A Study of Success and Failure in ERP Implementation: The Case of the Agricultural Products Processing Center
}

\author{
Jin Hyeung Kim ${ }^{1}$, Jung Rock Do $^{2}$ and Young Chan Choe $^{3}$ \\ ${ }^{1}$ First author, Seoul National University Agricultural Economics and Rural \\ Development, 200-8201, Gwanak-ro 1, Gwanak-gu, Seoul, 151-921 \\ ${ }^{2}$ Second author, Seoul National University Agricultural Economics and Rural \\ Development, 200-8201, Gwanak-ro 1, Gwanak-gu, Seoul, 151-921 \\ ${ }^{3}$ Corresponding author, Seoul National University Agricultural Economics and \\ Rural Development, 200-8201, Gwanak-ro 1, Gwanak-gu, Seoul, 151-921 \\ ${ }^{1}$ kijh3252@naver.com, ${ }^{2}$ dojungro79@naver.com, ${ }^{3}$ aggi@snu.ac.kr
}

\begin{abstract}
As the number of large-scaled Agricultural Products Processing Center (APC) increases, the introduction of the ERP system has been actively promoted in agriculture. Although there are effort to apply the ERP system in agriculture, successful cases of APC are rare because of the limitation of ERP system and lack of user's awareness. The purpose of the study is to derive success factors of ERP implementation by comparing two cases of APC which adopted ERP system. This study used 11 Critical Success Factor (CSF) to analyze whether two APCs had implemented these factors and to find the importance of CSF before and after ERP adoption. The implications of this study are as follow. The results of this study can minimize trial and error of APC that uses ERP system by sharing success factors. In addition, the government can use these factors as APC target selection index for ERP government business.
\end{abstract}

Keywords: ERP (Enterprise Resources Planning), APC (Agricultural Products Processing Center), CSF (Critical Success Factor), Information System

\section{Introduction}

The growth of large retail stores has created interest in government support to derive economies of scale in processed agricultural products. Specifically, the Agricultural Products Processing Center (APC) was established as a free trade agreement (FTA) funded business. Some organizations have emerged with more than 20 billion won. In general, operations, inventory and supply chain management have been applied at the APC. Thus, the government and private sector have been promoting the implementation of Enterprise Resources Planning (ERP) in order to enhance the operational efficiency of large-sized businesses. The ERP system manages production, logistics, finance, accounting, sales, purchasing and inventory in an integrated process. The ERP helps in the decision-making of new information by sharing information. In a narrow sense, the ERP System also denotes its own business software package [23, 24].

The purpose of ERP adoption is to construct integrated information systems and to enhance business processes. ERP adoption can simplify and standardize work to reduce stockpiling expenses, reduce payment terms, enhance information sharing and increase sales [4]. In addition, ERP can strengthen a company's competitiveness by enhancing consumer response systems, supplying high value information, and constructing global management systems. 


\begin{tabular}{|c|c|c|c|c|}
\hline \multirow{3}{*}{$\begin{array}{c}\text { ERP } \\
\text { Means of } \\
\text { Management reform }\end{array}$} & \multirow{3}{*}{$\begin{array}{c}\begin{array}{c}\text { Business process } \\
\text { innovation }\end{array} \\
\begin{array}{c}\text { Organizational } \\
\text { culture innovation }\end{array}\end{array}$} & Efficient Consumer Response system & & \\
\hline & & High value-added information & $\begin{array}{c}\text { Enhance } \\
\text { Competitiveness }\end{array}$ & $\begin{array}{l}\text { Customer satisfaction } \\
\text { profit maximization }\end{array}$ \\
\hline & & Global Management System & & \\
\hline
\end{tabular}

Figure 1. The Purpose of ERP Implementation

ERP systems are applied to various management activities. For the effective operation of an ERP system, it is necessary to consider specific factors in each field. In the case of agriculture, the production, distribution and sales processes are different from processes with the same names in general enterprises.

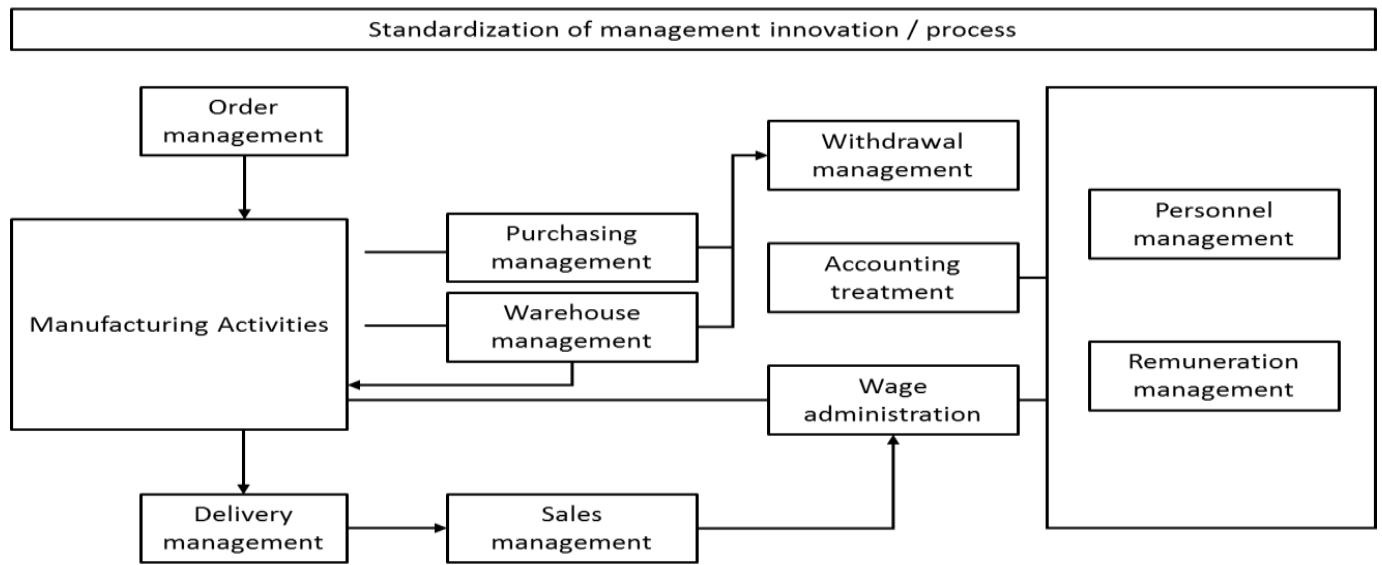

Figure 2. Process Structure of ERP

There have been several studies conducted to find ERP's construction schemes, management efficiency, success factors, and successful cases [1] [9]. However, in the agricultural field, most studies have focused on the expected effects of ERP adoption [5] and the cases of small-scaled agricultural businesses, such as the 'Pureundul' Agricultural Cooperative Association, and the Agricultural Corporation, 'Rosepia'. However, few studies have been conducted to find the success factors of ERP adoption at the APC, which has the biggest ERP system in the agricultural field.

The objectives of this study are to examine the literature on common ERP and specialized ERP systems for agriculture. We analyze the success and failure factors of two actual APC case studies in two regions. We investigate the background and status of ERP in agriculture. Through the two different cases and the effects of agricultural marketing, this study seeks to provide implications for agricultural product processing in the future.

\section{Background of ERP adoption and Literature Review}

In the early 1970s, Material Requirements Planning (MRP) was used for efficient production management. MRP minimizes the production of stock parts and performs a function for managing and supplying materials as per order requests at a suitable time and place. To do this, product component information, standard process chart, standard production scheme and production records are needed. MRP has problems as it dismisses the limitations of the demand for manufacturing resources and does 
not reflect changes in real time. In the 1980s, MRP II was developed to effectively manage all resources and materials for the purpose of cost reduction in response to the development of computers [24]. MRP II was developed as an intelligent production management tool by adopting production activity analyzing tools, such as scheduling algorithms and simulation. In the 1990s, with the growth of information and communications technology (ICT), ERP was added as a function that was not provided by MRP II. It was recognized that it is important to consider both top-down supply systems and associated departments during decision-making processes. ERP includes not only production and production management, but also business management support and other areas of management, such as design, finance, accounting, sales and human resources.

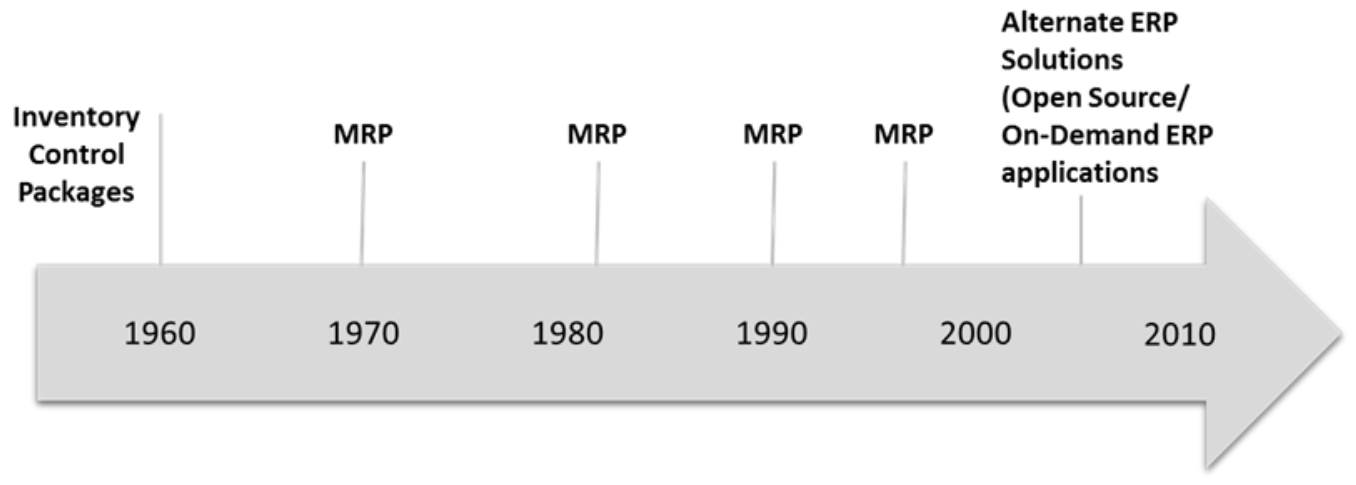

Figure 3. Evolution of ERP

Since the late 1990s, Korean companies have been attempting to revamp their business processes by using PI (Process Innovation) and BPR (Business Process Reengineering). During the same time, competitiveness decreased because of changes, such as higher personnel expenses, shortage of high-quality human resources, and insufficient social overhead capital, in the business environment. ERP emerged as an alternative following an interest in the adoption of new information systems and innovations in production strategy. Computational costs were reduced by constructing a system and ERP was needed in the enterprise production process. Federated ERP systems utilizing the evolution of the ERP and IT technology is in progress. There is also a business model that introduce the mobile and web-based ERP system [2, 19]. ERP was adopted in production and operation processes in various industries, each of which showed particular success and failure factors.

\section{Effect of the ERP System in Agriculture}

\subsection{The Development of the ERP System in Agriculture}

In 2002, Saenong and Kointech, as distributors of organic produce, were the first ERP adopters in South Korea (henceforth referred to as Korea). The purpose of ERP was to improve competitiveness through the efficiency of management. However, this purpose did not succeed because of the constraints of ERP technology and the lack of understanding on the part of the developers of agricultural products. Since 2007, the Korean government has recognized the need for an ERP system in agriculture. Thus, the Korean government implemented a policy for introducing the ERP system to one hundred agricultural firms. 
ERP adoption businesses have changed from an individual building type system to a single integrated construction method. The developmental stages of the ERP system in agriculture are as follows.

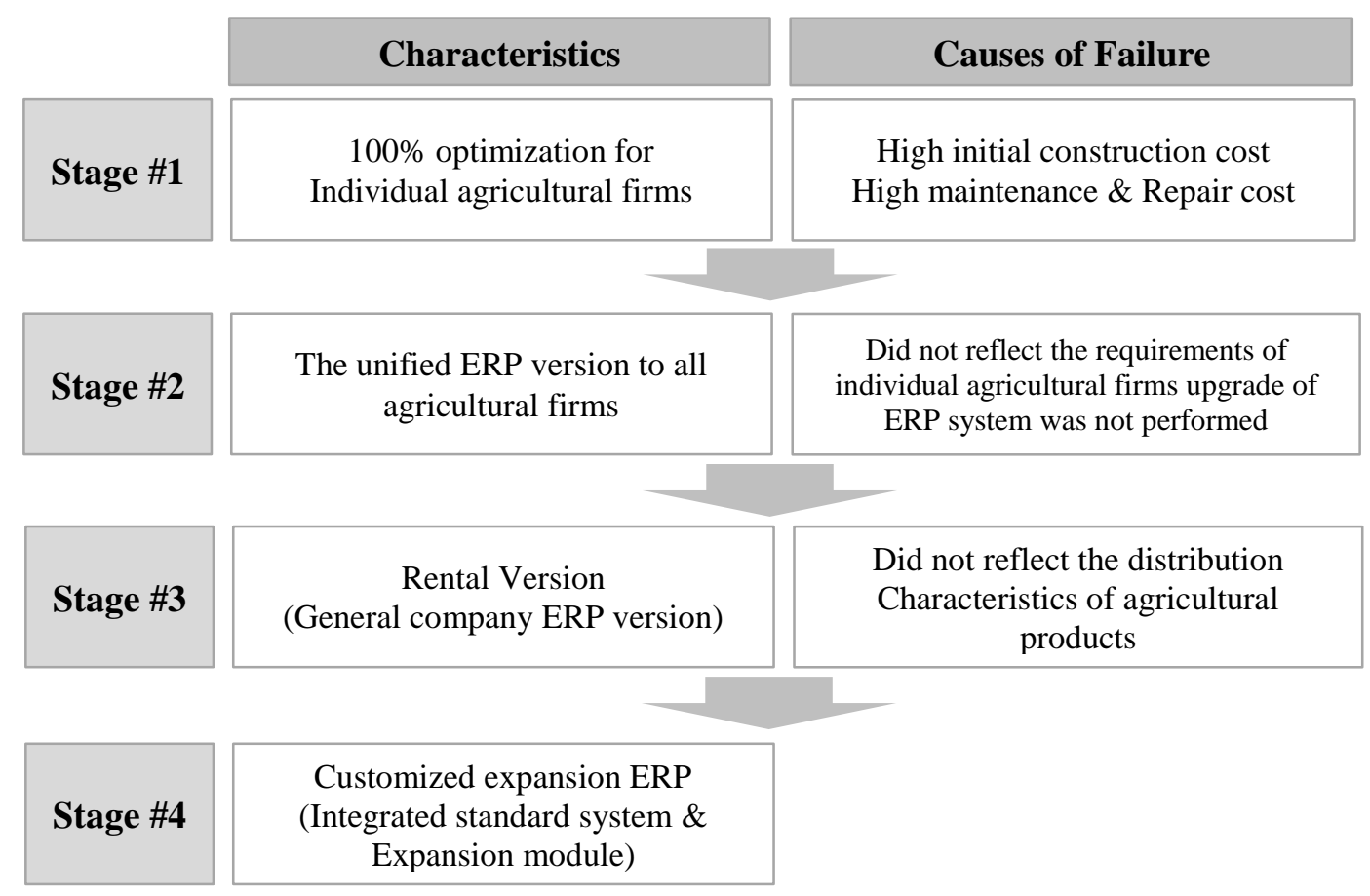

Figure 4. The Development Stages of the ERP System in Agriculture

In the first stage, the ERP system was constructed for $100 \%$ optimization for individual agricultural firms. However, the ERP system had high initial construction, maintenance and repair costs.

In the second stage of ERP adoption in agriculture, the unified version of ERP was adopted by agricultural firms. However, the adoption of the second generation ERP was minimal because the ERP system did not reflect the requirements of individual agricultural firms and continuous upgrades of the ERP system were not made.

In the third stage of ERP adoption in agriculture, ERP was a system that was rented. The ERP solutions services had become so large and preferred to target general companies. However, some of the agricultural firms had used the rental type of ERP solutions, which did not reflect the distribution characteristics of agricultural products. Thus, ERP solutions only operated for some functions or areas, such as accounting and tax management.

In the fourth stage of ERP adoption in agriculture, the ERP system had been developed as a production and distribution system with an integrated standard system and expansion module. The ERP system is based on a process that considers specific agricultural functions should be conducted. The ERP system also enhances flexibility and scalability in modularization, which reflects the business practices and characteristics of an agricultural firm. 


\subsection{Effect of the ERP System in Agriculture}

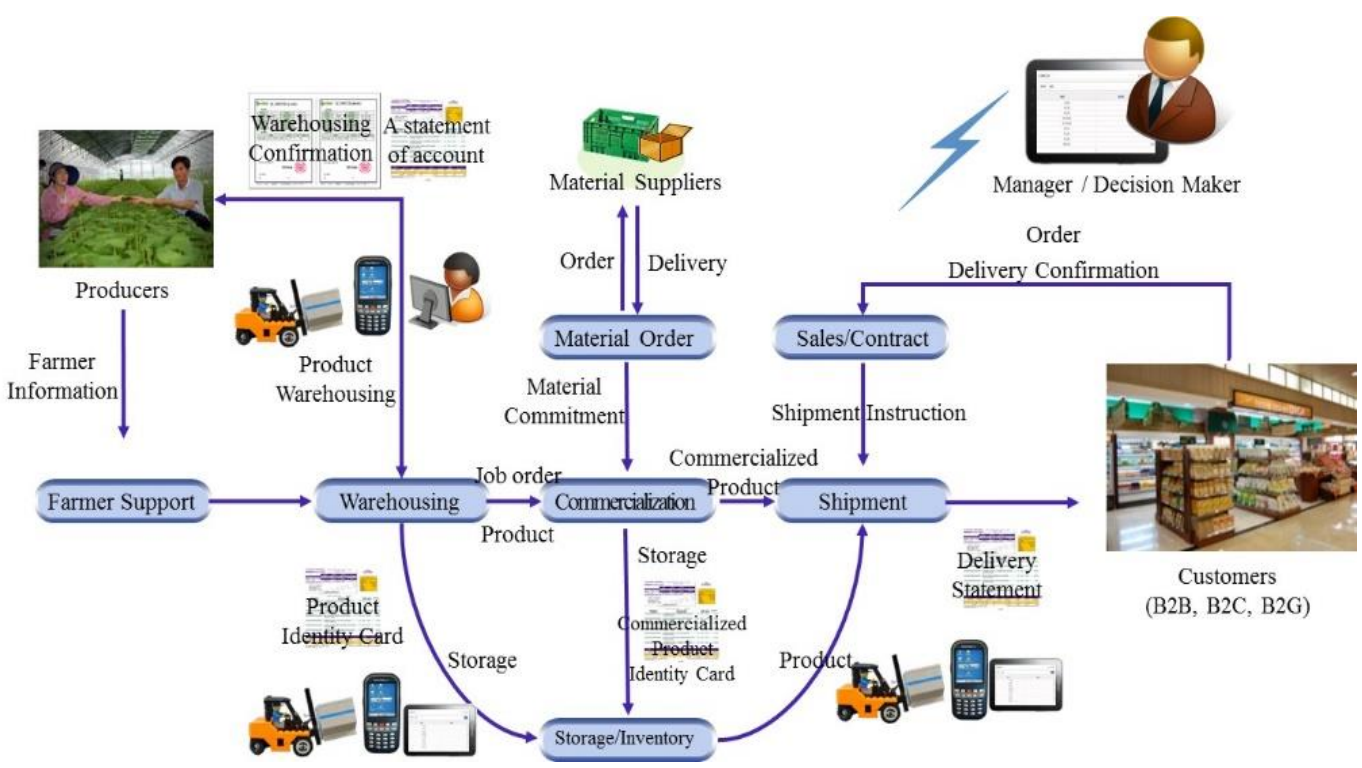

Figure 5. ERP System Flow Chart in APC

Agricultural products are characterized by the distribution process. A precise harvest yield is difficult to predict. Also, the inventory of agricultural products is difficult to manage because of the limitations in standardization. Based on the experience of farmers, the precise amount for a planting plan is difficult to calculate. Therefore, the introduction of an effective ERP system that clearly understands the situation in agriculture is necessary.

The effect of ERP system implementation is important. First, the ERP system enables the standardization of optimized business processes in the APC environment. Second, the ERP system can improve the accuracy of information, and centralize it in real time. Although individual information before ERP development has to be managed, the ERP system enables mutual information sharing by managing a central server after the ERP development. Therefore, the ERP system enables rapid decision-making by acquiring accurate data in real time. Third, the accuracy of inventory management is possible with ERP. Since agricultural products have perishable characteristics, ERP is an important part of cost savings for the accurate accounting of stored produce. Fourth, in the adoption of the ERP system, operational efficiency and transparency in conjunction with automated main equipment, such as a non-destructive sugar content sorting machine for example, can be greatly improved. If sorting information for a sophisticated selector and information cooperation is transmitted and received in real-time at a central server, a variety of inventory management techniques becomes possible to allow automatically configuring different specifications. Fifth, APC operational efficiency can be greatly improved. Lead time, which is the time from order to shipment, can be reduced by a real-time information sharing system. Also, since the system can provide the exact quality of the agricultural product using the "calculation" application, the effect can prevent conflicts associated with the calculation [22].

\subsubsection{Case \# 1: Agricultural Products Processing Center A:}

'APC A' is a facility that processes apples. The ERP system was introduced in 2009 to enhance operational efficiency, which is an important success factor that minimizes the load on field work when the ERP system is introduced step-by-step. After step 1 
(purchasing, production, storage and calculation) was introduced, step 2 (sales and delivery) of the ERP system was introduced in three steps (material receipts, payments and inventory). To minimize trial and error, employees had to accustom themselves to the system.

It was possible to implement an optimized ERP system using "the sustained maintenance and optimization" parameters, which is a key element in the success of the ERP system. This particular CEO at 'APC A' had a high understanding of and enthusiasm for ERP. The on-site person in charge of the utilization of the information system also played an important role.
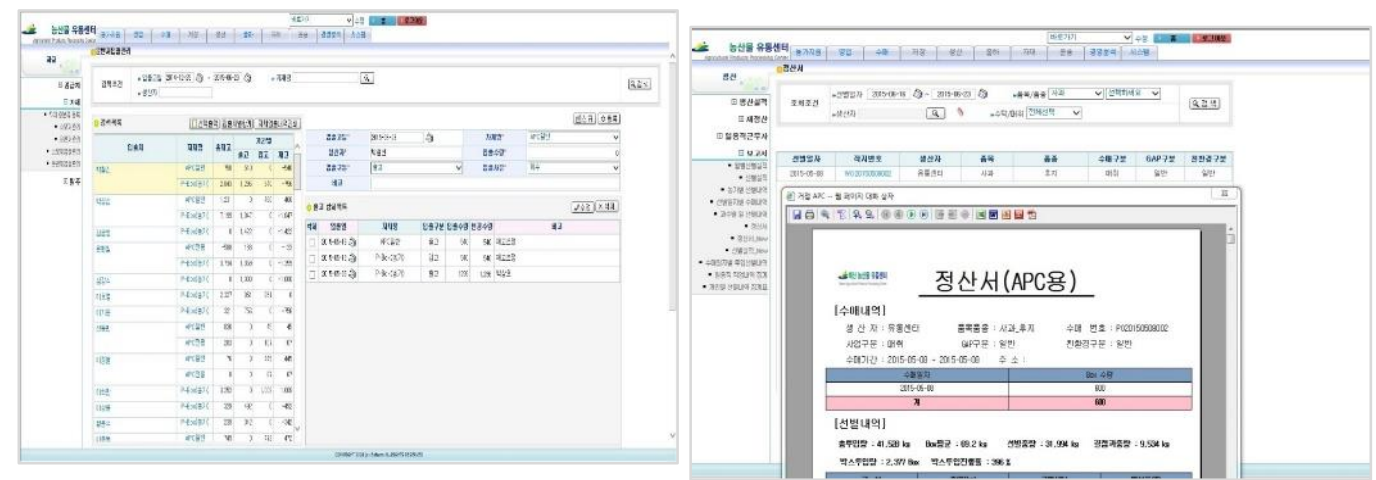

Figure 6. ERP Practical Program

\subsubsection{Case \# 2: Agricultural Products Processing Center B:}

'APC B' is the biggest apple product processing center and accounted for $8 \%$ production area and 10\% production amounts at the end of 2014. This center had introduced the ERP system in 2008. 'APC B' was also controlled by an agricultural cooperatives consignment management system, which was applied to all processes from farmers support and purchase until shipment. It was focused on being an economic integration system rather than a management support system.

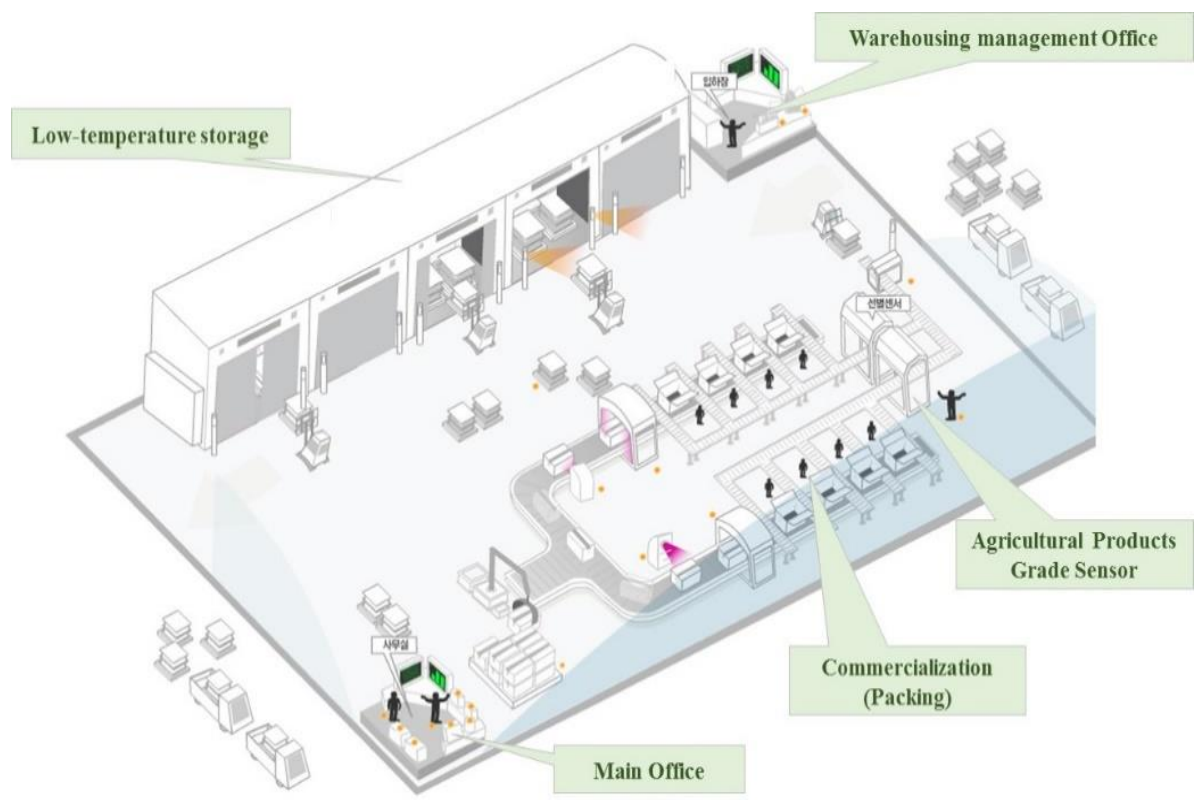

Figure 7. APC Institute Composition 


\section{Critical Success Factors for the implementation of ERP}

Author names and affiliations are to be centered beneath the title and printed in Times New Roman 12-point, non-boldface type. Multiple authors may be shown in a two or three-column format, with their affiliations below their respective names. Affiliations are centered below each author name, italicized, not bold. Include e-mail addresses if possible. Follow the author information by two blank lines before main text.

\subsection{Literature Review}

As ERP systems became popular, the research in related fields has consequently expanded. Most studies are focused on the success factors for ERP implementation [19, 12, 23], on ERP case studies [15], and empirical studies of ERP [3]. Most studies on success factors have concentrated on external environmental factors rather than system factors. Some research has investigated the success factors that were present through the IS Success Model and Technology Acceptance Model (TAM). Such research focused on the technology accommodation factors according to the implementation of the information system $[8,13,15,17]$.

In this study, we want to analyze the success factors from the management perspective rather than the validity of the ERP system application. As a result of the variables that affect the success of ERP, we selected Somers and Nelson's comprehensive list of $22 \mathrm{CSFs}$ for project/system implementation. This lists contains comprehensive indicators composed of IT implementation, business process re-engineering, project implementations and descriptions, and case studies of ERP implementation [26].

\subsection{Critical Success Factors}

The objective of this study are to investigate two Agricultural Products Processing Centers (APC) in Korea. One is an APC that uses an ERP system continuously, and another that does not use an ERP system after five years of adoption. A survey method was carried out by in-depth interviews and questionnaires with the Project Managers (PM) of the software vendor who had built the ERP system for each APC. Survey items were set on the basis of the indicator that was utilized in previous studies of success factors of general corporate ERP implementation. In addition, in view of the characteristics of Korean agriculture and APC, several new indicators have been added. The Critical Success Factors (CSF) are eleven. We investigated whether the two APCs had implemented these factors, and what their importance before and after ERP adoption was. The eleven critical success factors and their definitions are shown in Table 1.

Table 1. Critical Success Factors (CSF) and their Definitions

\begin{tabular}{|c|l|c|}
\hline $\begin{array}{c}\text { Critical Success } \\
\text { Factors }\end{array}$ & \multicolumn{1}{|c|}{ Definition } & Reference \\
\hline $\begin{array}{c}\text { Top management } \\
\text { support }\end{array}$ & $\begin{array}{l}\text { The degree of top manager support before and } \\
\text { after ERP implementation in APC }\end{array}$ & $\begin{array}{c}\text { Somers and } \\
\text { Nelson(2001) }\end{array}$ \\
\hline $\begin{array}{c}\text { Clear goals and } \\
\text { objectives }\end{array}$ & $\begin{array}{l}\text { Whether APC has set the goal and what level of } \\
\text { ERP adoption }\end{array}$ & $\begin{array}{c}\text { Somers and } \\
\text { Nelson(2001) }\end{array}$ \\
\hline $\begin{array}{c}\text { Practical hands-on } \\
\text { use by employees }\end{array}$ & $\begin{array}{l}\text { The degree of hands-on use by employees } \\
\text { before and after ERP implementation in APC }\end{array}$ & New Indicator \\
\hline $\begin{array}{c}\text { User training and } \\
\text { education }\end{array}$ & Training about ERP system use & $\begin{array}{c}\text { Somers and } \\
\text { Nelson(2001) }\end{array}$ \\
\hline $\begin{array}{c}\text { Training on new } \\
\text { business processes }\end{array}$ & $\begin{array}{l}\text { Education according to the new business } \\
\text { processes in ERP implementation }\end{array}$ & $\begin{array}{c}\text { Somers and } \\
\text { Nelson(2001) }\end{array}$ \\
\hline
\end{tabular}




\begin{tabular}{|c|l|c|}
\hline $\begin{array}{c}\text { Project team } \\
\text { competence }\end{array}$ & $\begin{array}{l}\text { Ability of ERP department or computing } \\
\text { department }\end{array}$ & $\begin{array}{c}\text { Somers and } \\
\text { Nelson(2001) }\end{array}$ \\
\hline Farmer education & $\begin{array}{l}\text { Education for the farmers participating in the } \\
\text { APC business }\end{array}$ & New Indicator \\
\hline $\begin{array}{c}\text { Vendor/customer } \\
\text { partnerships }\end{array}$ & $\begin{array}{l}\text { The level of cooperation between vendors and } \\
\text { users before and after ERP adoption }\end{array}$ & $\begin{array}{c}\text { Somers and } \\
\text { Nelson(2001) }\end{array}$ \\
\hline $\begin{array}{c}\text { Ongoing vendor } \\
\text { support }\end{array}$ & Ongoing post-management of software vendor & $\begin{array}{c}\text { Somers and } \\
\text { Nelson(2001) }\end{array}$ \\
\hline $\begin{array}{c}\text { Operational } \\
\text { management of } \\
\text { hardware }\end{array}$ & $\begin{array}{l}\text { Operating management entity of hardware } \\
\text { (servers, etc.) }\end{array}$ & New Indicator \\
\hline $\begin{array}{c}\text { Business process re- } \\
\text { engineering }\end{array}$ & $\begin{array}{l}\text { Enterprise business process redesign for } \\
\text { accomplishments }\end{array}$ & $\begin{array}{c}\text { Somers and } \\
\text { Nelson(2001) }\end{array}$ \\
\hline
\end{tabular}

Each factor was classified into three groups by level of importance. We requested that the Project Managers (PM) respond 'Neutral' if an individual APC had not considered a factor important at the time of ERP implementation. The other two levels were 'Somewhat important' and 'Extremely important'.

4.2.1. Top Management Support: The center manager has the decision-making authority for most of the work in the APC. Therefore, the support of the top manager can be seen as an important factor influencing the success or failure of ERP adoption in APC.

4.2.2. Clear Goals and Objectives: Setting clear objectives in introducing the new system will improve the likelihood of success. The ERP adoption of the APC was usually carried out with political support in Korea. So, the users can be passive when adopting the new system. This would require that the users can reduce the likelihood of failure to accommodate the system actively by setting a clear goal for the ERP implementation.

4.2.3. Practical Hands-On Use by Employees: It is a very important indicator if the administer has the willingness to use the ERP. The APC has no more than 10 managers and is not divided into departments. Thus, managers can see the necessity of ERP operation.

4.2.4. User Training and Education: Education and training are very important for the managers using am ERP system. As the ERP system is adapted to the APC and manages the whole operation various processes, such as warehousing, screening, storage, commercialization and settlement, managers should understand the whole process pf commercialization and the need to increase the utilization through education.

4.2.5. Education on New Business Processes: It is possible to modify business processes by ERP implementation. So, APC managers need education on newly modified work. The quality of education is a significant factor in the successful implementation of ERP.

4.2.6. Project Team Competence: Many general companies have a team of personnel to operate the system for dedicated computing. However, generally, APC mostly places the human resources in specific positions. So, there appears to be little difference depending on the APC service career and computing needs.

4.2.7. Farmer Education: After the farmers complete their sales for a year, they can receive the results of the settlement. The education with ERP settlement results compared with existing program results can be an important indicator for sustainable utilization by 
farmers. Continuously implementing the ERP promotion through education can increase the trust with APC and the settlement results.

4.2.8. Vendor/Customer Partnerships: The partnerships between software vendors and APC managers is a very significant factors for implementation of operations. Continuous feedback from the users for ERP adoption can develop into a more appropriate system.

4.2.9. Ongoing Vendor Support: ERP systems are constantly evolving. Therefore, it is important to consistently upgrade the system. Also, there is variation in the handling of products and in operations. Continuous support by the software vendor can have a positive effect for the successful implementation of ERP.

4.2.10. Operational Management of Hardware: If the ERP system is applied to the APC, server management is very important. If software and hardware managers are separated, the sustainability of the implementation may be reduced, so it is an important point for ERP success whether the software vendors manage their hardware.

4.2.11. Business Process Re-Engineering: Business process re-engineering means basically rethinking enterprise work process and fundamentally redesigning a new business model from the essential parts, such as costs, quality, services and velocity. A new business model and re-engineering are essential factors in ERP development [20].

\subsection{Results}

4.3.1. Case of ERP use: APC A: The results of the 'APC A' case study demonstrate that 8 out of 11 CSF were present. Pre-implementation had 2 'Extremely important', 4 'somewhat important', and 5 'Neutral' CSFs. Post-implementation had 4 'Extremely important', 6 'Somewhat important', and 1 'Neutral' CSFs.

Most of the ERP adoption success case studies had put emphasis on the period after the adoption phase than before the adoption phase.

Among the CSFs, 'User training and education' and 'Project team competence' had 'extremely important' for both pre- and post-implementation, indicating that these were the most important indicators. 'Practical hands-on use by employees' and 'Ongoing vendor support' were found to be the next important factors.

The results indicate that user's competency and continuous post management are ERP's important factors.

Table 2. The Results of APC A

\begin{tabular}{|c|c|c|c|}
\hline \multirow{2}{*}{ Critical Success Factors } & \multicolumn{3}{|c|}{ APC A } \\
\cline { 2 - 4 } & Implementation & Pre-Implementation & Post- Implementation \\
\hline Top management support & $\mathrm{O}$ & Somewhat important & Somewhat important \\
\hline Clear goals and objectives & $\Delta$ & Somewhat important & Somewhat important \\
\hline $\begin{array}{c}\text { Practical hands-on use by } \\
\text { employees }\end{array}$ & $\mathrm{O}$ & Somewhat important & Extremely important \\
\hline User training and education & $\mathrm{O}$ & Extremely important & Extremely important \\
\hline $\begin{array}{c}\text { Education on new business } \\
\text { processes }\end{array}$ & $\mathrm{O}$ & Neutral & Somewhat important \\
\hline Project team competence & $\Delta$ & Extremely important & Extremely important \\
\hline
\end{tabular}




\begin{tabular}{|c|c|c|c|}
\hline Farmer education & $\mathrm{O}$ & Neutral & Somewhat important \\
\hline $\begin{array}{c}\text { Vendor/customer } \\
\text { partnerships }\end{array}$ & $\mathrm{O}$ & Somewhat important & Somewhat important \\
\hline $\begin{array}{c}\text { Ongoing vendor support } \\
\text { Operational management of } \\
\text { hardware }\end{array}$ & $\mathrm{O}$ & Neutral & Extremely important \\
\hline $\begin{array}{c}\text { Business process } \\
\text { re-engineering }\end{array}$ & $\mathrm{X}$ & Neutral & Somewhat important \\
\hline
\end{tabular}

4.3.2. Case without ERP use: APC B: The results of the APC B case study demonstrate that 4 out of 11 CSFs were present. Pre-implementation had no 'Extremely important', 6 'somewhat important' and 5 'Neutral', and post-implementation had 1 'Extremely important', 5 'Somewhat important', and 5 'Neutral'. Top management support was found to be an important factor. Rather than there being a specific indicator, "somewhat important' was prevalent in overall indicators. Compared to APC A, APC B underscored on 'Ongoing vendor support' and 'Practical hands-on use by employees'.

The results indicate that 'Top management support' is the most important indicator in a general company [15]. In the Korean agricultural sector, actual ERP user's capability, level, and willingness are important factors for success in ERP implementation.

Table 3. The Results of APC B

\begin{tabular}{|c|c|c|c|}
\hline \multirow{2}{*}{ Critical Success Factors } & \multicolumn{3}{|c|}{ APC B } \\
\cline { 2 - 4 } & Implementation & Pre-Implementation & Post-Implementation \\
\hline Top management support & $\mathrm{O}$ & Somewhat important & Extremely important \\
\hline Clear goals and objectives & $\Delta$ & Somewhat important & Somewhat important \\
\hline $\begin{array}{c}\text { Practical hands-on use by } \\
\text { employees }\end{array}$ & $\Delta$ & Neutral & Neutral \\
\hline User training and education & $\mathrm{O}$ & Somewhat important & Somewhat important \\
\hline $\begin{array}{c}\text { Education on new business } \\
\text { processes }\end{array}$ & $\mathrm{O}$ & Somewhat important & Somewhat important \\
\hline Project team competence & $\Delta$ & Neutral & Neutral \\
\hline Farmer education & $\mathrm{O}$ & Neutral & Neutral \\
\hline $\begin{array}{c}\text { Vendor/customer } \\
\text { partnerships }\end{array}$ & $\Delta$ & Somewhat important & Somewhat important \\
\hline $\begin{array}{c}\text { Ongoing vendor support } \\
\text { Operational management of } \\
\text { hardware }\end{array}$ & $\Delta$ & Somewhat important & Somewhat important \\
\hline $\begin{array}{c}\text { Business process re- } \\
\text { engineering }\end{array}$ & $\mathrm{X}$ & Neutral & Neutral \\
\hline
\end{tabular}

\section{Conclusions}

In this study, we summarized the success factors of the ERP system used in agriculture and two case studies. By using two case studies, we are able to confirm what factors make successful implementation of ERP in APC. 
In conclusion, although 'Top management support' and 'Clear goals and objectives' are important factors to ERP system in general firms, the Critical Success Factors (CSFs) of ERP implementation in APC are user's competency and users' practical hands-on use.

In addition, ERP consulting is essential before introducing the system. Through prior consulting, business process needs to be schematized. In addition, interest in the utilization of ERP system from CEO (Chief Executive Officer) and business managers needs to be raised. Then, considering the organization's capability and characteristic, decision needs to be made whether to adopt ERP system at once or stage by stage. After introducing the ERP system, ongoing maintenance for optimizing the operating system occurred at the APC. In the long term, we must enhance the introduction of the ERP system through ERP systems development manuals and APP, DBMS, and hardware management.

There are two practical implications of this study. The results of this study can minimize trial and error to APC that uses ERP system by sharing success factors. In addition, the government can use these factors as APC target selection index for ERP government business.

\section{Acknowledgements}

This research was supported by the MSIP (Ministry of Science, ICT and Future Planning), Korea, under the C-ITRC (Convergence Information Technology Research Center) (IITP-2015-H8601-15-1007) supervised by the IITP (Institute for Information \&communications Technology Promotion).

\section{References}

[1] C.P. Holland and B. Light, "A critical success factors model for ERP implementation", IEEE software, (1999).

[2] E. Asfoura, G. Kassem and R. Dumke, "Characterization of business model for federated ERP systems", International Journal of u- and e- Service, Science and Technology, vol. 3, no. 4, (2010) December.

[3] E. K. Joe and D. H. Min, "Factors Affecting the Usage of an ERP System in Operation: A Socio-technical View with User Orientation", Journal of the Korea Society of IT Services, vol. 9, no. 2, (2010), pp. 129-149.

[4] H. J. O and S. W Han, "Articles: A Study on the ERP System", Journal of Regional Studies and Development, vol. 5, no. 1, (2005).

[5] H. S. Shin, "Expectation Effects of ERP Introduction for Distribution Center at Agricultural Products Center", J. Agr. Sci., vol. 18, (2007), pp. 85-95.

[6] J. S. Kim and S. K. Choi, "Construction and Estimation of Web-based Real Time ERP System A Case Study", Journal of Korea Contents Association, vol. 8, no. 4, (2008), pp. 30-38.

[7] J. S. Lee, "the Development Process and Direction Suggestion of ERP", Korean Institute of Information Technology. vol. 6, no. 3, (2008), pp. 192-199.

[8] K. C. Lee and N. Chung, "Understanding Factors Affecting Trust in and Satisfaction with Mobile Banking in Korea”, A modified DeLone and McLean's Model Perspective, Interacting with computers, vol. 21, no. 5, (2009), pp. 385-392.

[9] K. B. Walhovd, A. M. Fjell, I. Reinvang and A. Lundervold, "The functional and structural significance of the frontal shift in the old/new ERP effect", Brain research, (2006).

[10] K. H. Kim, "Critical Success Factors in Global ERP Systems Implementation Based on Global Single Instance", Journal of Internet E commerce research, vol. 9, no. 1, (2009), pp. 215-231.

[11] K. S. Choi and C. M. Koo, "A case of Information system construction in Agricultural Corporation Rosepia", The Korea Society of Management Information Systems, (2010).

[12] M. Y. Park, "The Successful Implementation Factors of the ERP System: The Cases of Small and Medium Businesses", In-Ha University Master's Degree, (2009).

[13] S. Petter and E. R. McLean, "A Meta-Analytic Assessment of the DeLone and McLean IS Success Model: an Examination of IS Success at the Individual Level", Information \& Management, vol. 46, Issue 3, (2009), pp. 159-166.

[14] R. Plant and L. Willcocks, "Critical success factors in international ERP implementations: a case research approach", Journal of Computer Information, (2007).

[15] S. Bueno and J. L. Salmeron, "TAM-based success modeling in ERP", Interacting with Computers, vol. 20, Issue 6, (2008). 
[16] S. R. Kim and J. H. Bae, "A Design and Implementation of a Web-based Ship ERP(SHERP)", The Journal Of Korean Institute Of Communications And Information Sciences, vol. 36, no. 6, (2011), pp. 710-719.

[17] S. Sternad and S. Bobek, "Impacts of TAM-based External Factors on ERP Acceptance", Proceeding a Technology, vol. 9, (2013), pp. 33-42.

[18] L. P. Willcocks and R. Sykes, "Enterprise resource planning: the role of the CIO and it function in ERP”, Communications of the ACM, (2000).

[19] Y. E. Gelogo and H. K. Kim, "Mobile Integrated Enterprise Resource Planning system architecture", International Journal of Control and Automation, vol. 7, no. 3, (2014), pp. 379388.

[20] Y. E. Choi and I. Lim, "Pureundul Agricultural Cooperative Association (PACA): A Case Study on ERP Adoption in a Small Firm", The Journal of Small Business Innovation, vol. 16, no. 1, (2013), pp. 51-59.

[21] Y. M Kwon, "Study of Success factors and User's Satisfaction on ERP System", Journal of Management Education, vol. 4, (2004), pp. 43-59.

[22] H. D. Park, Production/distribution information system report, (2015).

[23] J. P. Laudon and K. C. Laudon, "Management Information Systems", Pearson Education, (2010).

[24] K. S. Noh and N. J. Cho, "Management Information Systems", scitechmedia, (2010).

[25] L. Fang and S. Patrecia, "Critical success factors in ERP Implementation", Independent thesis Advanced level, Jonkoping International Business School, (2005).

[26] T. M. Somers and K. Nelson, "The Impact of Critical Success Factors across the Stages of Enterprise Resource Planning Implementations", HICSS '01 Proceedings of the 34th Annual Hawaii International Conference on System Sciences (HICSS-34), vol. 8, (2001).

\section{Authors}

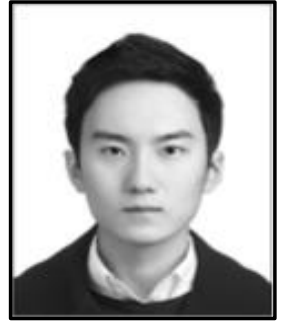

Jin Hyeung Kim, He received the BS in the department of Economics \& International Area studies from Handong Global University in 2014 . He is currently a master course student in the Graduate school of Agricultural Economics and Rural Development, Seoul National University. His current research interests include agricultural management information systems, e-business in the agriculture, and big data analysis.

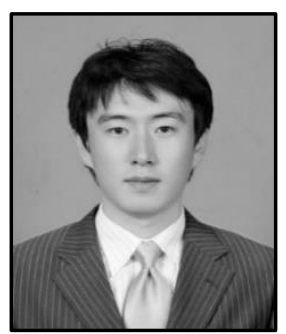

Jung Rock Do, He received the BS in the department of Agriculture \& Natural Resources from Michigan State University in 2006. Currently, he is a master course student in the Graduate school of Agricultural Economics and Rural Development, Seoul National University. His research interests include agricultural information systems, agricultural products distribution, supply chain management.

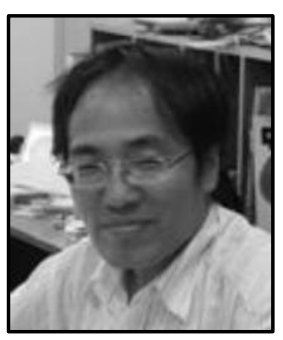

Young-Chan Choe, He received the MS and Ph.D in Department of Agricultural Economics from Michigan State University in 1989 and 1991, respectively. He is currently a Professor in Seoul National University. His current research interests include agricultural information systems, e-business in the food and agricultural sector, and big data analysis. 